\title{
Evaluation of Citrullus sp. Germ Plasm for Resistance to Acidovorax avenae subsp. citrulli
}

\author{
D. L. Hopkins and C. M. Thompson, University of Florida, Mid-Florida Research and Education Center, Apopka \\ 32703
}

\begin{abstract}
Hopkins, D. L., and Thompson, C. M. 2002. Evaluation of Citrullus sp. germ plasm for resistance to Acidovorax avenae subsp. citrulli. Plant Dis. 86:61-64.

In the greenhouse, 1,344 Citrullus spp. and Praecitrulllus fistulosus accessions were screened for resistance to Acidovorax avenae subsp. citrulli. Seedlings were inoculated at the first true leaf stage by misting with a water suspension of a virulent strain of A. avenae subsp. citrulli originally isolated from commercial watermelon in Florida in 1989. Seedlings were considered resistant if less than $20 \%$ of the cotyledons were necrotic and there were no lesions on the true leaves 10 days after inoculation. Twelve accessions had individual seedlings that were resistant to A. avenae subsp. citrulli. Selfs of seven of these accessions were susceptible in greenhouse and field tests. Selfs were obtained from five accessions from Zimbabwe and Zambia that possessed a level of greenhouse and field resistance to A. avenae subsp. citrulli that could provide control of bacterial fruit blotch of watermelon. Based on field evaluations, plant introduction (PI) 482279 and PI 494817 were judged to contain plants with the best sources of resistance; however, PI 500303, PI 500331, and PI 482246 also had plants with high levels of resistance.
\end{abstract}

In 1989, bacterial fruit blotch (BFB) of watermelon (Citrullus lanatus), caused by Acidovorax avenae subsp. citrulli (formerly Pseudomonas pseudoalcaligenes subsp. citrulli), was first observed in commercial production areas in the United States $(8,12)$. In some fields, losses were more than $90 \%$ of the total marketable fruit. The characteristic symptom of BFB that renders the fruit unmarketable is the greasy-appearing, water-soaked, dark, olive-green stain, or blotch, that develops on the upper surface of infected fruit (7). Fruit lesions begin as small water-soaked areas with irregular margins that often expand to cover the upper surface of the watermelon. Eventually, lesions turn brown and cracks appear, allowing secondary organisms to invade and rot the fruit. A. avenae subsp. citrulli also produces symptoms on seedlings and leaves. On seedlings, water-soaked lesions are produced on hypocotyls and cotyledons, sometimes causing collapse and death of the seedling. Light-brown to reddishbrown leaf lesions often develop along the

Corresponding author: D. L. Hopkins

E-mail: dhop@gnv.ifas.ufl.edu

Florida Agricultural Experiment Station Journal Series No. R-08023.

This research was supported by the United States Department of Agriculture, National Plant Germplasm System.

Accepted for publication 4 October 2001.

Publication no. D-2001-1120-03R

(C) 2002 The American Phytopathological Society midrib, but leaf symptoms also can be inconspicuous. Leaf lesions usually do not result in defoliation, but are most important as reservoirs of bacteria for fruit infection later in the season. BFB of watermelon has occurred in one or more watermelon-producing states in the eastern United States every year since 1989 (10). Severe epidemics developed in Georgia in 1992 and throughout the eastern United States in 1994 (5). In 1994, thousands of hectares of watermelon in at least 10 states were affected.

A bacterial fruit rot of watermelon, with symptoms identical to those described for $\mathrm{BFB}$ in 1989, was reported to have occurred in 1967-68 on watermelon plant introductions (PI) grown on the experiment station at Leesburg, FL (1). The etiology of this fruit rot was not determined. BFB in Guam (14) and the eastern United States $(2,8,12)$ is caused by strains of $A$. avenae subsp. citrulli that are similar, or identical, to strains reported to cause disease on certain PI seedlings in Georgia in 1965 (15). Commercial watermelon seedlings were found to vary significantly in their resistance to the bacterium obtained from PI seedlings in Georgia (3). Resistance to this bacterium was identified in PI 295843 and PI 299378, which were considered as sources of resistant genes (13). However, in 1989-90, seedlings of these two PIs were as susceptible to A. avenae subsp. citrulli as were seedlings of 22 watermelon cultivars, and inoculated fruit of both PIs developed BFB symptoms (6).

The best control measure for BFB of watermelon that is currently available is to prevent the introduction of the bacterium into the field. The intensive efforts of the seed industry and the transplant industry to produce seeds and transplants free of $A$. avenae subsp. citrulli have reduced significantly the incidence of BFB over the last five to six seasons (D. L. Hopkins, unpublished data). In spite of these efforts, the bacterium still appears in a few fields every year, and BFB was a significant problem in some states again in the 2000 season. In addition to infested seed and infected transplants, the bacterium can invade a field from contaminated volunteer watermelons, other cultivated cucurbits, and wild cucurbits $(7,9,11)$. The only control option for fruit blotch once it infests a field is multiple applications of coppercontaining fungicides (4). Other control strategies are needed and resistance is generally considered an ideal control.

The objective of this study was to evaluate the U.S. collection of Citrullus spp. and Praecitrullus fistulosus accessions for sources of resistance to BFB of watermelon. We chose to evaluate resistance in seedlings in the greenhouse and to confirm any sources of resistance by field evaluation of foliar symptoms. Foliar resistance could prevent inoculum buildup in the field and eliminate the source of bacteria for the devastating fruit symptoms.

\section{MATERIALS AND METHODS}

Twenty-five seeds each of all Citrullus and Praecitrullus fistulosus accessions evaluated were obtained from the U.S. plant germ plasm collection at the Plant Genetic Resources Conservation Unit at Griffin, GA. A Florida strain of A. avenae subsp. citrulli (WFB89-1) isolated in 1989 from a commercial watermelon cultivar was used throughout these tests. Strains obtained from commercial watermelon fields in 1989 through 1994 were similar in virulence to WFB89-1. This strain has given reproducible, severe symptoms on commercial varieties (6).

Screening for resistance to A. avenae subsp. citrulli was conducted on seedlings of 1,344 Citrullus and Praecitrullus fistulosus accessions. In the winter of 1994-95 and the summer of 1995, 675 accessions that had been added to the U.S. germ plasm collection over the previous 20 years were evaluated. In the summer of 1997 and winter of 1997-98, 669 watermelon accessions that have been in the collection for more than 20 years were screened. Accessions were grown in the 
greenhouse in a commercial soil mix (Fafard Mix No. 2-S; Conrad Fafard, Inc., Agawam, MA) in plastic trays $26 \mathrm{~cm}$ wide by $52 \mathrm{~cm}$ long by $6 \mathrm{~cm}$ deep. Each tray was planted with eight seeds each of four accessions and the susceptible control cv. Charleston Gray in five rows running the width of the tray. To minimize seasonal effects on the tests, eight-seed samples of all accessions were run in the winter (November to April) and a second screening of all accessions was conducted in the summer (May to August).

For inoculations, WFB89-1 was grown on nutrient agar for $48 \mathrm{~h}$ and washed from the agar surface with sterile, deionized water. Bacterial suspensions were adjusted to $A_{600 \mathrm{~nm}}=0.25$ with a spectrophotometer and diluted 100 -fold with sterile water $\left(10^{5}\right.$ to $10^{6} \mathrm{CFU} / \mathrm{ml}$ ). Seedlings were inoculated at the first true leaf stage (approximately 2 weeks after planting) by misting with the bacterial suspension until runoff using a hand-sprayer bottle. After inoculation, seedlings were placed in a moist chamber on the greenhouse bench for $48 \mathrm{~h}$. The moist chamber consisted of 4-mil, clear, plastic greenhouse covering on a wood frame $120 \mathrm{~cm}$ wide by $126 \mathrm{~cm}$ long by 25 $\mathrm{cm}$ deep. Eight plastic trays of watermelon seedlings were placed under the chamber. The table under the plastic chamber was lined with water-soaked paper towels to maintain a relative humidity of 95 to $100 \%$ under the chamber. If temperatures in the moist chamber became higher than $40^{\circ} \mathrm{C}$ between 10:00 A.M. and 4:00 P.M., the plastic chambers were raised approximately 10 $\mathrm{cm}$ on one side to allow air circulation and cooling. After $48 \mathrm{~h}$ in the moist chamber, inoculated seedlings were placed in a greenhouse, where temperatures ranged

Table 1. Accessions of Citrullus demonstrating some resistance to Acidovorax avenae subsp. citrulli in greenhouse tests

\begin{tabular}{llcccc}
\hline & & \multicolumn{3}{c}{ Average disease rating $^{\mathbf{x}}$} & \\
\cline { 3 - 5 } PI $^{\mathbf{y}}$ & Origin & Winter test & Summer test & Low-high rating & Resistant/total $^{\mathbf{z}}$ \\
\hline 532811 & China & 5.5 & 4.5 & $1-9$ & $6 / 16$ \\
482279 & Zimbabwe & 6.2 & 4.8 & $3-9$ & $6 / 16$ \\
385964 & Kenya & 4.8 & 6.0 & $3-9$ & $5 / 12$ \\
494817 & Zambia & 8.2 & 3.0 & $2-9$ & $4 / 16$ \\
482246 & Zimbabwe & 4.2 & 8.1 & $3-9$ & $4 / 16$ \\
241689 & Chile & 4.0 & 9.0 & $3-9$ & $4 / 9$ \\
254742 & Senegal & 5.1 & 9.0 & $3-9$ & $4 / 16$ \\
500331 & Zambia & 8.7 & 6.6 & $4-9$ & $2 / 15$ \\
254736 & Senegal & 6.0 & 6.6 & $3-9$ & $2 / 16$ \\
381748 & India & 9.0 & 7.1 & $4-9$ & $2 / 16$ \\
225557 & Zimbabwe & 6.0 & 9.0 & $4-9$ & $1 / 8$ \\
500303 & Zambia & 7.9 & 6.1 & $3-9$ & $1 / 16$ \\
\hline
\end{tabular}

$\bar{x}$ Disease ratings were made 10 days after inoculation using a scale based on symptom appearance, where 1 = no symptoms; 2 = few small, necrotic lesions on cotyledons; $3=$ small, necrotic lesions on cotyledons, $<20 \%$ necrotic cotyledon; $4=$ small, necrotic lesions on $>20 \%$ of cotyledon; $5=$ necrotic lesions with chlorosis on cotyledons, $20-50 \%$ necrotic cotyledon; $6=$ necrotic lesions on $20-50 \%$ of cotyledon with restricted lesions on true leaf; $7=$ large spreading lesions, $>50 \%$ of cotyledon necrotic with restricted lesions on true leaves; $8=$ large spreading lesions, $>50 \%$ of cotyledon necrotic with lesions and chlorosis on true leaves; and $9=>90 \%$ necrosis of the cotyledon and large spreading lesions on the true leaves, or a dead plant.

y Plant introduction inventory number. PI 381748 is Praecitrullus fistulosus; all others are Citrullus lanatus.

${ }^{\mathrm{z}}$ Number of plants with a disease rating $<5$ over the total number of plants tested.
Selfs of resistant seedlings were screened for resistance to A. avenae subsp. citrulli in the greenhouse, as described above for the original accessions. During the 1996, 1997, and 1999 spring watermelon seasons, four replications of two 7.6-m rows containing five hills per row of the selfed accessions were direct-seeded into the field at the Mid-Florida Research and Education Center in Leesburg. Rows were $3 \mathrm{~m}$ apart. One week prior to thinning (4 to 5 weeks after planting), the watermelon plants were inoculated by misting with the bacterial suspension as described above. Foliar disease ratings were made in the field 2 weeks after anthesis using a scale based on the proportion of leaves with lesions, where 1 = no foliar symptoms, $3=$ necrotic lesions on approximately $25 \%$ of leaves, $5=$ necrotic lesions on $50 \%$ of leaves, $7=$ necrotic lesions on approximately $75 \%$ of leaves, and $9=$ necrotic lesions on most leaves. Fruit from these selfed accessions also were observed at maturity for symptoms of bacterial fruit blotch. Foliar disease ratings data were subjected to analysis of variance using the general linear models procedure of SAS (SAS Institute, Cary, NC). The Duncan's new multiple range test at $P=0.05$ was used for mean separation.

\section{RESULTS}

Of the 1,344 Citrullus and Praecitrullus fistulosus accessions screened for resistance to A. avenae subsp. citrulli in the greenhouse, most were highly susceptible, with an average disease rating between 8 and 9 on the 1-to- 9 scale. These accessions were very susceptible both in the test conducted in the winter and the one conducted in the summer; however, there was an overall tendency for symptoms to be more severe in the hot, humid summer months.

Approximately 80 of the accessions had individual seedlings that appeared to have some resistance to A. avenae subsp. citrulli (disease rating $<5$ ). Reinoculation of these apparently resistant seedlings, either in the greenhouse or after transplanting into the field, resulted in severe symptom development in most. The seedlings that developed symptoms after reinoculation either were escapes in the first inoculation or were inoculated when temperature and humidity were less favorable for symptom development. However, a few of the accessions had seedlings that were resistant to $A$. avenae subsp. citrulli after reinoculation (Table 1). All of these accessions were segregating for resistance, because several individual seedlings were very susceptible (disease rating of 9) in each of these accessions.

Accessions PI 532811 (China), PI 482279 (Zimbabwe), and PI 385964 (Kenya) were the most consistently resistant in the winter and summer evaluations, and the most resistant individuals were selected from these three accessions (Table 1). Bacterial fruit blotch is more severe in 
hot, humid weather and most of the accessions tested more resistant in the winter evaluation than in the summer test (i.e., PI 241689, PI 482246, PI 254742, PI 254736, and PI 225557). However, PI 494817, PI 500331, and PI 500303 from Zambia and PI 381748 from India were more resistant in the summer test than in the winter. PI 494817 had the lowest disease rating in the summer test. Some of the accessions (PI 500331, PI 381748, PI 225557, and PI 500303) were highly susceptible to $A$. avenae subsp. citrulli except that a single seedling, or two, appeared to be resistant. Selfs were obtained from all of these accessions.

In greenhouse tests, selfs of two of the original accessions with the lowest disease ratings in the tests, PI 532811 and PI 385964, were more susceptible than the original accession seedlings (Table 2). Because of this, PI 532811 was not evaluated in the field and PI 38564 was evaluated in the field only in 1996. Selfed seed of PI 532811 germinated poorly; only eight seedlings were available for evaluation. Selfs of PI 482279 had a lower average disease rating (were more resistant) in greenhouse tests than the original accession seedlings and a similar rating to the seedling that was selfed. Over $80 \%$ of the selfs of PI 482279 had a seedling disease rating $<5$. Selfs of resistant seedlings of PI 494817, PI 500303, PI 500331, and PI 482246 also had low disease ratings, indicating probable resistance. Selfs of resistant seedlings of PI 254736, PI 254742, PI 241689, PI 225557, and PI 381748 had a high disease rating and no apparent resistance to A. avenae subsp. citrulli.

In the field tests, selfs of PI 482279 had the lowest percentage of leaves with symp- toms in all three years of the tests (Table 2). In the two years that selfs of PI 494817 were tested, they also had very low levels of disease. Selfs of PI 500303, PI 500331, and PI 482246 were not as resistant as the two accessions mentioned above, but appeared to have a level of resistance that may be adequate. The selfs of the other six accessions had more foliar symptoms and were evaluated in only 1 year each.

PI 482279 fruit were pumpkin shaped and had a light-green rind with dark stripes. The flesh of the fruit was peach colored and tough. Seeds were medium in size and brown. PI 494817 melons were round and dark green. Flesh of the fruit was cream in color and tough. Seeds were black and large. Fruit of PI 500303 was oblong with a mottled dark- and lightgreen rind. Flesh of the melons was peach in color and tough in texture. Seeds were light brown and medium sized. PI 500331 produced small, round, dark-green fruit with tough, white flesh. Seeds were brown and small. PI 482246 produced pumpkinshaped fruit with a light-green rind with dark-green stripes. The yellow flesh of the fruit was tough. Seeds were reddish brown and medium sized.

\section{DISCUSSION}

Of 1,344 Citrullus and Praecitrullus fistulosus accessions screened for resistance to A. avenae subsp. citrulli in the greenhouse, five appeared to have genes for resistance to $A$. avenae subsp. citrulli that could be useful in a watermelon breeding program. PI 482279 and PI 494817 had the lowest percentage of diseased leaves in the field and were judged to be the best sources of resistance. However, PI 500303, PI 500331, and PI 482246 also could be valuable sources of genes for resistance. The five accessions with likely sources of resistance to A. avenae subsp. citrulli all were from Zimbabwe or Zambia.

The greenhouse screening procedure used in this study was effective in revealing differences in resistance among individual seedlings that generally agreed with field results. Interestingly, some accessions had lower disease ratings in the winter greenhouse test than in the summer and some had lower disease ratings in the summer. Of the 12 accessions from which we obtained selfs, 6 appeared more resistant in the summer tests and 6 in the winter tests. Four of the five accessions that were finally judged to be the best sources of genes for resistance to A avenae subsp. citrulli in this study had lower disease ratings (were more resistant) in the summer seedling tests than in the winter tests; whereas, only one of the five accessions that are sources of resistant genes had less disease in the winter tests than in the summer tests. Perhaps there were escapes in the winter screening tests due to slightly cooler greenhouse temperatures and lower relative humidity during cold periods. Thus, running the greenhouse screening procedure in the summer when conditions are most favorable for BFB development was the best way to screen for resistance that also was effective in the field.

While the major loss to BFB of watermelon is due to fruit symptoms (10), the resistance that was identified in the accessions was a foliar resistance. Foliar resistance prevents fruit symptoms by eliminating the foliage as a reservoir of bacteria to infect the fruit. Although there was no effort made to screen for resistance in the fruit (with 1,344 accessions that would

Table 2. Evaluation of selfs of accessions of Citrullus for resistance to Acidovorax avenae subsp. citrulli in greenhouse and field tests

\begin{tabular}{|c|c|c|c|c|c|c|c|}
\hline \multirow[b]{2}{*}{$\mathbf{P I}^{\mathbf{y}}$} & \multirow[b]{2}{*}{ Origin } & \multicolumn{2}{|c|}{ Average disease ratingw } & \multirow[b]{2}{*}{ Resistant/total ${ }^{\mathrm{z}}$} & \multicolumn{3}{|c|}{ Average field rating $x$} \\
\hline & & Original & Selfs & & 1996 & 1997 & 1999 \\
\hline 482279 & Zimbabwe & 5.5 & 3.5 & $14 / 17$ & $0.8 \mathrm{a}$ & $1.3 \mathrm{a}$ & $0.8 \mathrm{a}$ \\
\hline 494817 & Zambia & 5.6 & 3.3 & $31 / 47$ & $1.4 \mathrm{ab}$ & $1.7 \mathrm{ab}$ & $\ldots$ \\
\hline 500303 & Zambia & 7.0 & 3.8 & $17 / 25$ & $1.4 \mathrm{ab}$ & $2.4 \mathrm{~b}$ & $\ldots$ \\
\hline 500331 & Zambia & 7.7 & 4.1 & $24 / 39$ & $2.0 \mathrm{bc}$ & $1.6 \mathrm{ab}$ & $\ldots$ \\
\hline 482246 & Zimbabwe & 6.2 & 3.9 & $24 / 37$ & $2.4 \mathrm{c}$ & $\ldots$ & $\ldots$ \\
\hline 385964 & Kenya & 5.4 & 7.4 & $6 / 41$ & $3.9 \mathrm{~d}$ & $\ldots$ & $\ldots$ \\
\hline 254736 & Senegal & 6.3 & 7.9 & $2 / 48$ & $\ldots$ & $\ldots$ & $3.7 \mathrm{c}$ \\
\hline 254742 & Senegal & 7.1 & 8.0 & $1 / 50$ & $\ldots$ & $\ldots$ & $3.1 \mathrm{bc}$ \\
\hline 241689 & Chile & 6.5 & 7.7 & $8 / 43$ & $\ldots$ & $\ldots$ & $3.6 \mathrm{bc}$ \\
\hline 381748 & India & 8.0 & 8.6 & $2 / 48$ & $\ldots$ & $\ldots$ & $2.3 \mathrm{~b}$ \\
\hline 532811 & China & 5.0 & 8.6 & $0 / 8$ & $\ldots$ & $\ldots$ & $\ldots$ \\
\hline 225557 & Zimbabwe & 7.5 & 8.9 & $0 / 50$ & $\ldots$ & $\ldots$ & $3.8 \mathrm{c}$ \\
\hline
\end{tabular}

${ }^{\mathrm{w}}$ Disease ratings on original accessions and selfs of accessions were made 10 days after inoculation using a scale based on symptom appearance, where 1 $=$ no symptoms; 2 = few small, necrotic lesions on cotyledons; $3=$ small, necrotic lesions on cotyledons, $<20 \%$ necrotic cotyledon; $4=$ small, necrotic lesions on $>20 \%$ of cotyledon; $5=$ necrotic lesions with chlorosis on cotyledons, $20-50 \%$ necrotic cotyledon; $6=$ necrotic lesions on $20-50 \%$ of cotyledon with restricted lesions on true leaf; $7=$ large spreading lesions, $>50 \%$ of cotyledon necrotic with restricted lesions on true leaves; $8=$ large spreading lesions, $>50 \%$ of cotyledon necrotic with lesions and chlorosis on true leaves; and $9=>90 \%$ necrosis of the cotyledon and large spreading lesions on the true leaves, or a dead plant.

${ }^{x}$ Foliar disease ratings were made in the field 2 weeks after anthesis using a scale based on the proportion of the leaves with lesions, where $1=$ no foliar symptoms, 3 =necrotic lesions on approximately $25 \%$ of leaves, $5=$ necrotic lesions on $50 \%$ of leaves, $7=$ necrotic lesions on approximately $75 \%$ of leaves, and $9=$ necrotic lesions on most leaves. Means followed by different letters within a column are significantly different by Duncan's new multiple range test, $P=0.05$ level.

y Plant introduction inventory number. PI 381748 is Praecitrullus fistulosus; all others are Citrullus lanatus.

${ }^{\mathrm{z}}$ Number of plants with a disease rating $<5$ over the total number of plants tested. 
have been too costly both in field space and in time), fruit from the selfs in the field tests were observed for symptom development and BFB was not observed on fruit of any of the five resistant accessions, so fruit resistance also may be present (data not shown). The horticultural traits of the five resistant accessions are not very desirable; therefore, numerous backcrosses to commercial watermelon cultivars will be needed to incorporate resistance to $A$. avenae subsp. citrulli into a commercially acceptable cultivar. In a watermelon breeding program, it will be much easier to screen for this foliar resistance in seedlings in a greenhouse than it would be to screen for fruit resistance.

The best control of BFB of watermelon is exclusion of the pathogen (7). If this could always be accomplished, there would be no need for resistance in commercial watermelon cultivars. Although efforts to sell only seed free of $A$. avenae subsp. citrulli have been successful in reducing the amount of BFB that occurs each year, there are still significant losses in some years. If resistance to A. avenae subsp. citrulli were incorporated into commercial watermelon cultivars, it could make it easier to produce seed that are free of the bacterium. A. avenae subsp. citrulli would not build up on the foliage in seed production fields and, thus, would not infect the seed. Resistant cultivars also would not become infected from diseased watermelons or other cucurbits that may be growing in the same transplant house or in an adjacent field. The incorporation of genes for resistance to $A$. avenae subsp. citrulli obtained from one of the five accessions with resistance could compliment the continued efforts to produce disease-free seed to control BFB of watermelon.

\section{ACKNOWLEDGMENTS}

We thank the USDA-ARS Plant Genetic Resources Conservation Unit at Griffin, GA for supplying the germ plasm for this study.

\section{LITERATURE CITED}

1. Crall, J. M., and Schenck, N. C. 1969. Bacterial fruit rot of watermelon in Florida. Plant Dis. Rep. 53:74-75.

2. Evans, T. A., and Mulrooney, R. P. 1991. First report of watermelon fruit blotch in Delaware. Plant Dis. 75:1074.

3. Goth, R. W., and Webb, R. E. 1981. Resistance of commercial watermelon (Citrullus lanatus) to Pseudomonas pseudoalcaligenes subsp. citrulli. Plant Dis. 65:671-672.

4. Hopkins, D. L. 1991. Chemical control of bacterial fruit blotch of watermelon. Proc. Fla. State Hortic. Soc. 104:270-272.

5. Hopkins, D. L., Cucuzza, J. D., and Watterson. J. C. 1996. Wet seed treatments for the control of bacterial fruit blotch of watermelon. Plant Dis. 80:529-532.
6. Hopkins, D. L., Thompson, C. M., and Elmstrom, G. W. 1993. Resistance of watermelon seedlings and fruit to the fruit blotch bacterium. HortScience 28:122-123.

7. Latin, R. X., and Hopkins, D. L. 1995. Bacterial fruit blotch of watermelon: The hypothetical exam question becomes reality. Plant Dis. 79:761-765.

8. Latin, R. X., and Rane, K. K. 1990. Bacterial fruit blotch of watermelon in Indiana. Plant Dis. 74:331.

9. Latin, R. X., Tikhonova, I., and Rane, K. K. 1995. Factors affecting the survival and spread of Acidovorax avenae subsp. citrulli in watermelon transplant production facilities. Phytopathology 85:1413-1417.

10. Maynard, D. N., and Hopkins, D. L. 1999 Watermelon fruit disorders. HortTechnology 9:155-161.

11. Rane, K. K., and Latin, R. X. 1992. Bacterial fruit blotch of watermelon: Association of the pathogen with seed. Plant Dis. 76:509-512.

12. Somodi, G. C., Jones, J. B., Hopkins, D. L., Stall, R. E., Kucharek, T. A., Hodge, N. C., and Watterson, J. C. 1991. Occurrence of a bacterial watermelon fruit blotch in Florida. Plant Dis. 75:1053-1056.

13. Sowell, G., Jr., and Schaad, N. W. 1979. Pseudomonas pseudoalcaligenes subsp. citrulli on watermelon: Seed transmission and resistance of plant introductions. Plant Dis. Rep. 63:437-441.

14. Wall, G. C., and Santos, V. M. 1988. A new bacterial disease on watermelon in the Mariana Islands. (Abstr.) Phytopathology 78:1605.

15. Webb, R. E., and Goth, R. W. 1965. A seedborne bacterium isolated from watermelon. Plant Dis. Rep. 49:818-821. 